\title{
Pemanfaatan GGBFS Sebagai Bahan Tambah Aduk Mortar
}

\author{
Nursyafril $^{1}$, Muhammad Taufan ${ }^{2}$ \\ ${ }^{1,2}$ Jurusan Teknik Sipil, Politeknik Negeri Bandung \\ E-mail: nursyafrilanwar@yahoo.com
}

\begin{abstract}
ABSTRAK
Ground Granulated Blast Furnace Slag (GGBFS) adalah limbah hasil pembakaran pada tanur tinggi yang bisa dimanfaatkan sebagai bahan bangunan yang diperoleh dengan cara penggilingan kerak. Bahan ini memiliki sifat pozolanik, sehingga dapat dimasukkan sebagai salah satu bahan aditif material pada campuran mortar. Penggunaan GGBFS sebagai bahan aduk mortar jarang sekali ditemui. Hal ini mengingat aduk mortar bukanlah digunakan sebagai bahan pembentuk bangunan struktural, melainkan hanya untuk bangunan non- struktural sehingga kurang mendapat perhatian yang lebih. Padahal penggunaan aduk mortar sangat menentukan kualitas bangunan secara keseluruhan, baik menyangkut estetika maupun kenyamanan. Penelitian ini memanfaatkan GGBFS sebagai bahan tambah untuk bahan tambah dari aduk mortar. Tujuannya adalah untuk mengetahui pengaruh penambahan GGBFS terhadap aduk mortar, baik dalam kondisi mortar segar maupun mortar keras. Sebagai bahan tambah, besarnya penambahan GGBFS ke dalam aduk mortar, dengan 3 macam variasi, yaitu 0\%, 2\%, 4\%, dan 6\% terhadap berat semen. Komposisi aduk mortar yang digunakan pada penelitian ini adalah 1 Pc : 3 Psr berdasarkan perbandingan berat. Dari hasil pengujian terhadap sifat mortar, adanya penambahan GGBGS dapat meningkatkan plastisitas, waktu pengikatan awal dan kekuatan mortar. Besarnya penambahan GGBFS yang paling optimal adalah sebanyak 6\%, karena sifat mortar segar dapat meningkatkan plastisitas sebesar 5\% dan peningkatan waktu pengikatan sebesar 7,83 \%.juga meningkatkan kekuatan mortar setelah mengeras sebesar $6 \%$.
\end{abstract}

Kata Kunci : GGBFS, bahan tambah, mortar

\begin{abstract}
Ground Granulated Blast Furnace Slag (GGBFS) is a combustion waste product of a high furnace that can be used as building material. This material has pozzolanic properties, so it can be included as one of the additive materials in mortar. As additive material, GGBFS rarely using. It cause the mortar is not a structural building material, but only for non-structural buildings. In fact mortar will effect to aesthetics and comfort of the building. The aim of the study is to determine the effect of GGBFS addition on mortar, both in fresh and hard mortar conditions. As addition material, the amount of GGBFS added to the mortar mixture namely $0 \%, 2 \%, 4 \%$, and 6\% of cement weight. Mortar mixture composition used in this study was 1Pc: 3 Fine Aggregate based on weight ratio. The most optimal addition of GGBFS is 6\%, with an increase in plasticity of $5 \%$ and an increase in binding time of $7.83 \%$, also increasing mortar strength by $6 \%$.
\end{abstract}

Keywords: GGBFS, additive material, mortar

\section{PENDAHULUAN}

\subsection{Latar Belakang}

Perkembangan teknologi mortar dewasa ini sangatlah pesat. Hal ini ditandai dengan digunakannya mortar yang memiliki kualitas lebih baik, ditinjau dari kekuatan, kemudahan dikerjakan, keawetan maupun tingkat kekedapannya. Peningkatan mutu mortar ini terjadi karena adanya penggunaan bahan tambah mortar serta semakin banyak aduk mortar dijualnya dalam keadaan kering dalam bentuk kemasan yang penggunaannya cukup dilakukan dengan menambah air (mortar instant) yang memiliki mutu bahan yang lebih baik tentunya. Penggunaan bahan tambah untuk aduk mortar, yang sering digunakan pada umumnya adalah bahan tambah jenis pozolanik yang bersifat aktif, yaitu bahan tambah yang mampu mengikat kapur bebas yang keluar dari hasil reaksi antara semen dengan air, dan membentuk senyawa yang keras sekaligus dapat mengurangi tingkat porositas jika memiliki ukuran butirannya lebih halus dari semen sehingga dapat mengisi rongga-rongga di antara butiran agregat dan semen sehingga berfungsi sebagai bahan filler.

Tetapi penggunaan bahan tambah pozolanik aktif sebagai bahan tambah untuk aduk mortar jarang sekali diterapkan di lapangan. Mungkin karena aduk mortar umumnya digunakan untuk pekerjaan arsitektur yang bersifat non struktural, sehingga antusiasme meningkatkan mutu mortar dengan memanfaatkan bahan pozolanik tidak sepesat pada beton. Padahal bahan pozolan ini dapat berfungsi sebagai bahan perekat, sehingga bila kita dapat mengurangi sebagian bahan semen. 
Hasil penelitian terhadap bahan pozolanik jenis GGBFS sudah terbukti dapat meningkatkan kekuatan serta mengurangi kerusakan pada beton. Struktur beton yang mengandung hingga 50\% GGBFS sebagai bahan ganti semen dianggap cocok untuk penggunaan struktur bangunan, jalan dan jembatan (Li, Li, \& Yuan, 2012).

Adanya kandungan material aktif, seperti oksida silika pada GGBFS sangat berpengaruh signifikan terhadap kuat tekan mortar (Putri, 2017). Atas dasar itu maka penulis tertarik untuk mengkaji pemanfaatan bahan pozolanik jenis $G G B F S$ yang diproduksi PT. Semen Indonesia sebagai bahan tambah dalam pembuatan aduk mortar.

Dari hasil penelitian ini diharapkan dapat diketahui persentase penambahan GBBFS tersebut sebagai bahan tambah yang paling optimal dalam penggunaannya sebagai bahan campuran aduk mortar.

\subsection{Perumusan Masalah}

Aduk mortar yang baik, adalah jika aduk mortar tersebut memiliki plastisitas yang baik pada saat mortar segar dan memiliki kekuatan yang lebih tinggi dari kekuatan tekan rencana. Dengan kinerja aduk mortar yang baik, tentunya akan membuat aduk mortar dapat meningkatkan kekuatan pasangan batu, baik sebagai bahan perekat pasangan batu maupun sebagai bahan plester pasangan batu. Untuk meningkatkan kinerja aduk mortar, maka peneliti merencanakan penelitian menambahkan bahan $G G B F S$ ke dalam aduk mortar.

Permasalahannya adalah seberapa besar pengaruh penggunaan GGBFS tersebut terhadap sifat mortar, baik dalam kondisi segar maupun setelah mengeras. Untuk mengetahui pengaruh penambahan GGBFS tersebut, maka perlu dilakukan pengkajian dengan melakukan uji laboratorium terhadap mortar dengan berbagai variansi jumlah penambahan $G G B F S$ sebagai bahan tambah aduk mortar.

\subsection{Tujuan penelitian ini :}

a. Menentukan pengaruh penambahan variasi GGBFS terhadap sifat fisik maupun mekanis mortar dalam kondisi plastis maupun setelah mengeras, sekaligus untuk mengetahui optimasi besarnya penggunaan GGBFS di dalam aduk mortar.

b. Meningkatkan pemanfaatan GGBFS sebagai bahan tambah untuk aduk mortar.

\section{TINJAUAN PUSTAKA}

\subsection{Pengertian Mortar}

Mortar adalah bahan bangunan berbahan dasar semen yang digunakan sebagai "perekat" untuk membuat struktur bangunan. Yang membedakan mortar dengan semen, sebenarnya mortar adalah semen siap pakai yang komponen pembentuknya umumnya adalah semen itu sendiri, agregat halus (pasir), air, dan berbagai jenis bahan tambah yang sesuai (Saripoelman, 2009).

Berdasarkan bahan pembentuknya, jenis mortar dapat dibagi dalam beberapa jenis, antara lain:

1. Mortar semen Portland

Mortar semen Portland (sering dikenal dengan mortar semen) dibuat dengan mencampurkan antara semen Portland (OPC), pasir, dan air.

2. Mortar semen polimer

Mortar semen polimer $(P C M)$ dibuat dengan menggantikan sebagian pengikat semen pada mortir semen konvensional oleh polimer sebagai bahan tambah. Bahan tambah polimer ini memiliki keunggulan permeabilitas rendah dan mengurangi kejadian pengeringan retak akibat penyusutan, terutama dirancang untuk memperbaiki struktur bangunan beton yang mengalami kerusakan.

3. Mortar kapur

Mortar kapur adalah jenis mortar yang bahan pencampurnya terdiri dari kapur, pasir, dan air.

4. Mortar posolan

Posolan adalah bahan tambah baik yang berasal dari alam atau limbah industri yang mengandung silika dan alumina yang jika dicampur dengan air akan bereaksi dengan kapur bebas. Mortar posolan adalah campuran antara mortar semen yang ditambahkan dengan posolan.

Berdasarkan kekuatannya, SNI 03-6882-2002 membagi jenis mortar ke dalam 4 jenis, yaitu :

a. Mortar tipe M adalah mortar yang mempunyai kekuatan 17,2 MPa.

b. Mortar tipe $\mathrm{S}$ adalah mortar yang mempunyai kekuatan $12,5 \mathrm{MPa}$.

c. Mortar tipe $\mathrm{N}$ adalah mortar yang mempunyai kekuatan 5,2 MPa.

d. Mortar tipe $\mathrm{O}$ adalah mortar yang mempunyai kekuatan 2,4 MPa. 


\subsection{Bahan-Bahan Mortar}

\subsubsection{Semen}

Di dalam mortar fungsi semen adalah sebagai bahan pengikat yang berbentuk butiran halus yang dengan penambahan air akan berubah menjadi pasta yang dapat mengikat agregat halus (pasir pasang) menjadi suatu masa yang keras dan padat. Jenis semen menurut SNI 15-2049-1994 ada 5 tipe, yang antara lain :tipe I, tipe II, tipe III, tipe IV dan tipe V. Kelima tipe semen ini digunakan untuk bahan campuran aduk beton struktural dan kondisi khusus. Di pasaran kelima tipe semen Portland sudah tidak diproduksi lagi (kecuali ada pemesanan).

Untuk bahan campuran aduk mortar yang memiliki kekuatan antara 2,4 - 17,2 MPa, maka sebaiknya menggunakan semen yang ada di pasaran, dengan mutu yang lebih rendah dari kelima jenis semen di atas, yaitu semen jenis Portland composite cement (PCC) atau Pozzolan Portland Cement (PPC) yaitu, semen hidrolik yang dibuat dengan menggiling terak, gipsum, dan bahan pozzolan baik yang bersifat aktif dan tidak aktif. Kedua jenis semen ini banyak beredar di pasaran sebagai semen pengganti kelima jenis semen. Semen PCC dan PPC memang baik digunakan untuk bahan aduk mortar karena bersifat ramah lingkungan dan jenis semen ini memiliki ketahanan sulfat dan panas hidrasi sedang.

\subsubsection{Agregat}

Agregat adalah butiran yang berfungsi sebagai bahan pengisi dalam campuran mortar dan beton. Mengingat penggunaan agregat sangat dominan dalam aduk mortar, maka sifat dari agregat yang digunakan akan sangat berpengaruh sekali terhadap sifat-sifat mortar yang dihasilkan. Dalam teknologi mortar, agregat yang digunakan adalah agregat halus. Agregat halus ini memiliki ukuran butir kurang dari 4,75 $\mathrm{mm}$

Syarat-syarat agregat yang digunakan untuk adukan pasangan (mortar) menurut SNI 03-6820-2002 sebagai berikut:

a. Tidak mengandung zat organik.

b. Kadar lumpur maksimum $5 \%$.

c. Gradasi agregat harus sesuai dengan tabel 1

Tabel 1. Gradasi agregat halus untuk mortar

\begin{tabular}{|c|c|c|}
\hline \multirow{2}{*}{$\begin{array}{c}\text { Saringan } \\
(\mathrm{mm})\end{array}$} & \multicolumn{2}{|c|}{ Lolos Kumulatif (\%) } \\
\cline { 2 - 3 } & Pasir alam & Pasir olahan \\
\hline 4,75 & 100 & 100 \\
\hline 2,36 & $90-100$ & $95-100$ \\
\hline 1,18 & $70-100$ & $70-100$ \\
\hline 0,60 & $40-75$ & $40-75$ \\
\hline 0,30 & $10-35$ & $20-40$ \\
\hline 0,15 & $2-15$ & $10-25$ \\
\hline 0,075 & 0 & $0-10$ \\
\hline
\end{tabular}

\subsubsection{Bahan Posolan}

Bahan posolan adalah bahan tambah mortar yang digunakan untuk meningkatkan kinerja dari sifat mortar, baik pada saat mortar dalam keadaan plastis (segar) ataupun setelah mengeras. Bahan posolan ini ada 2 jenis yaitu ada yang aktif dan tidak aktif. Bahan posolan yang aktif dapat bereaksi dengan kapur bebas hasil reaksi semen dengan air membentuk senyawa baru yang dapat mengeras sehingga akan meningkatkan kekuatan dari aduk yang dibuat setelah mengeras. Sedangkan bahan posolan yang tidak aktif, umumnya berfungsi sebagai bahan untuk meningkatkan kelecakan dan bahan pengisi saja. Akan tetapi karena berat jenis bahan posolan yang tidak aktif, maka penggunaan bahan posolan jenis ini dapat mengurangi mutu mortar yang dihasilkan.

Berdasarkan Tjokrodimuljo, 2002 pozzolan adalah bahan yang terbentuk secara alami maupun hasil rekayasa yang mengandung senyawa silika dan alumina. Bahan pozzolan itu sendiri tidak mempunyai sifat mengikat seperti semen, akan tetapi dalam bentuknya yang halus dan dengan adanya air, senyawa tersebut akan dapat bereaksi secara kimia dengan kalsium hidroksida pada suhu biasa membentuk senyawa yang memiliki sifat-sifat seperti semen (kalsium silikat dan kalsium alumina hidrat).

Jenis bahan-bahan posolan yang terbentuk secara alami antara lain: tufa, abu vulkanis, tanah diatomae, sedangkan yang termasuk pozzolan buatan adalah : pozzolan hasil pembakaran tanah liat, hasil pembakaran batu bara berupa fly ash, abu dari bahan organik (seperti sekam padi, serabut kelapa sawit, serat tebu dan lain-lain) yang dibakar pada suhu diatas $600^{\circ} \mathrm{C}$, silica fume, yaitu bahan posolan yang halus dengan diameter berkisar antara 0,1-1,0 micron yang mengandung komposisi silika lebih banyak dari hasil sampingan tanur tinggi atau sisa produksi silikon atau alloy besi silicon (ASTM.C.1240,1995: 637-642) serta Ground Blast Furnace Slag (GBFS) adalah kerak (slag) merupakan hasil residu pembakaran tanur tinggi adalah produk non-metal yang 
merupakan material berbentuk butiran/granular. Kerak Unsur GBFS sebagian besar terdiri dari kapur, silika dan alumina yang terkandung di dalam besi saat dimasukkan ke dalam tanur. GBFS bila digiling halus akan memiliki sifat sangat reaktif yang dapat dipakai sebagai bahan pengganti semen GBFS yang sudah digiling halus di sebut Ground Granulated Blast Furnace Slag (GGBFS).

\subsection{Pengaruh Penggunaan Bahan Posolan terhadap Sifat Mortar}

Pemanfaatan GGBFS akan menguntungkan bagi aspek lingkungan karena bahan ini termasuk bahan limbah. Bahan ini dapat digunakan sebagai bahan pengganti semen sehingga dapat mengurangi biaya konstruksi karena berkurangnya penggunaan semen dan pada aspek kekuatan struktur bahwa beton dengan GGBFS lebih baik dari pada beton tanpa GGBFS (Siddique \& Kaur, 2011).

Reaksi antara silika dengan kalsium hidroksida (kandungan kapur bebas dalam semen Portland) berlangsung dalam jangka waktu yang lama. Kuat tekan dan kuat aus optimal beton dengan penambahan tumbukan batu bata sebagai pozzolan akan dicapai setelah beton berumur minimal 90 hari (Tjokrodimuljo, 1996)

Menurut Ermiyati (Jurnal Sains dan Teknologi 6(2), September 2007: 31-34) Penggunaan bahan pozolan yang terbuat dari abu kelapa sawit terhadap sifat terhadap mortar, ternyata semakin besar persentase abu kelapa sawit dalam mortar, maka semakin besar pula nilai daya resap airnya sekaligus menurunkan berat jenis dan kuat tekannya. Begitu pula dengan Penggantian sebagian semen dengan abu kelapa sawit pada adukan mortar ternyata mengurangi kekedapan mortar, dan semakin besar persentasenya semakin membuat mortar tidak kedap air.

Menurut Md. Moinul Islam, Md. Saiful Islam, Bipul Chandra Mondal and Mrita Das (Journal of Civil Engineering .IEB, 37 .2.2009. 111-122) penggantian semen dengan abu hasil penggilingan terak besi (GGBFS) dengan perbandingan $70: 30$ dan nilai faktor air semen 0,46 dapat meningkatkan kekuatan mortar dan ketahanan mortar terhadap sulfat.

\section{METODE PENELITIAN}

\subsection{Pendahuluan}

Kinerja aduk mortar sangatlah ditentukan oleh bahan pembentuknya. Dengan adanya penambahan GGBFS ke dalam aduk mortar akan dapat terlihat pengaruhnya terhadap kinerja dari aduk mortar yaitu pada saat aduk masih dalam kondisi segar maupun setelah aduk tersebut mengeras. Penentuan besarnya perubahan sifat aduk mortar untuk setiap variasi penambahan $G G B F S$ dapat diketahui dengan membandingkannya dengan aduk mortar tanpa penambahan GGBFS. Diharapkan dengan kajian ini akan dapat diketahui efektivitas penambahan $G G B F S$ terhadap aduk mortar, ditinjau dari sifat fisik maupun mekanis aduk mortar yang dihasilkan.

Tahapan pelaksanaan kajian laboratorium terhadap sifat-sifat dari aduk mortar yang menggunakan bahan tambah $G G B F S$ dengan variasi berbeda dapat terlihat pada gambar 1.

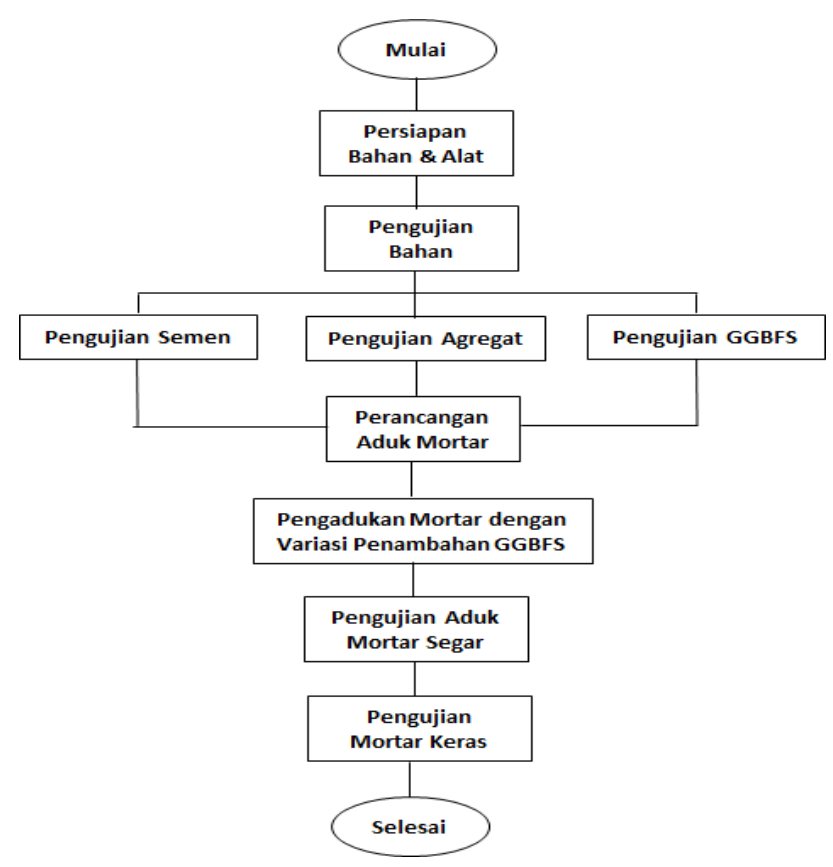

Gambar 1. Diagram alir Kajian Laboratorium 


\subsection{Teknik Pengambilan Data}

Data yang diperlukan selain data yang sudah diperoleh dari hasil studi sebelumnya, juga data primer yang diperoleh dari hasil pengujian langsung terhadap beberapa benda uji uji. Adapun benda yang dibuat dan diuji adalah sebagai berikut:

a. Pengujian bahan-bahan aduk mortar, antara lain GGBFS, pasir dan semen, dapat dilihat pada tabel 2.

Tabel 2. Pengujian Bahan Mortar

\begin{tabular}{|c|c|c|c|}
\hline No & Jenis Pengujian & Metoda Uji & $\begin{array}{c}\text { Jumlah Sampel } \\
\text { (buah) }\end{array}$ \\
\hline \multicolumn{3}{|c|}{ Semen } \\
\hline 1 & Berat Jenis & ASTM C.188-92 & 2 \\
\hline 2 & Bobot Isi & SNI 03-1973-1990 & 2 \\
\hline \multicolumn{5}{|c|}{ GGBFS } \\
\hline 1 & Berat Jenis & ASTM C.188-92 & 2 \\
\hline 2 & Kehalusan & SNI 15-2049-2004 & 2 \\
\hline 3 & Keaktifan & NI 20- 1965 & 2 \\
\hline 4 & Bobot Isi & SNI 03-1973-1990 & 2 \\
\hline \multicolumn{5}{|c|}{ Pasir } \\
\hline 1 & Berat Jenis \& Penyerapan & SNI 1969:2008 & 2 \\
\hline 2 & Bobot Isi & SNI 03-4804-1989 & 2 \\
\hline 3 & Gradasi & SNI 03-1968-1990 & 2 \\
\hline 4 & Kadar lolos no. 200 & SNI ASTM C 117:2002 & 2 \\
\hline 5 & Kadar Zat Organik & SNI 03-2816-1992 & 2 \\
\hline
\end{tabular}

b. Pemeriksaan aduk mortar segar, yang meliputi konsistensi dan waktu pengikatan dapat dilihat pada tabel 3 .

Tabel 3. Pengujian Mortar Segar

\begin{tabular}{|c|l|c|c|}
\hline No & \multicolumn{1}{|c|}{ Jenis Pengujian } & Metoda Uji & $\begin{array}{c}\text { Jumlah Sampel } \\
\text { (buah) }\end{array}$ \\
\hline \multicolumn{3}{|c|}{ Mortar Segar } \\
\hline 1 & $\begin{array}{l}\text { Konsisitensi dengan Flow } \\
\text { Table }\end{array}$ & ASTM C 305-82 & 4 \\
\hline 2 & Bobot Isi & ASTM C 188-92 & 4 \\
\hline 3 & $\begin{array}{l}\text { Waktu Pengikatan dengan } \\
\text { Hand Penetrometer }\end{array}$ & ASTM C 403-95 & 4 \\
\hline
\end{tabular}

c. Pemeriksaan aduk mortar setelah mengeras, yang meliputi berat isi dan kuat tekan pada umur tertentu

Tabel 4. Pengujian Mortar Keras

\begin{tabular}{|c|l|c|c|}
\hline No & Jenis Pengujian & Metoda Uji & $\begin{array}{c}\text { Jumlah Sampel } \\
\text { (buah) }\end{array}$ \\
\hline \multicolumn{4}{|c|}{ Mortar Keras } \\
\hline 1 & Bobot Isi & ASTMC 188-92 & 24 \\
\hline 2 & Kuat Tekan & ASTMC 114-69 & 24 \\
\hline
\end{tabular}

\subsection{Teknik Analisis Data}

Metode analisa terhadap sifat aduk mortar, dilakukan dengan cara membandingkan karakteristik aduk mortar yang menggunakan variasi penambahan GGBFS dengan aduk mortar tanpa menggunakan GGBFS sebagai pembanding. Untuk mengetahui besarnya pengaruh penambahan $G G B F S$, maka dalam penelitian ini dilakukan kajian terhadap aduk mortar keras untuk umur mortar keras tertentu, khususnya untuk mortar pada 28 hari yang telah mencapai hidrasi sempurna. Dengan variasi umur tersebut akan terlihat perubahan berat isi, penyerapan dan kuat tekan dari aduk mortar keras untuk setiap variasi penambahan GGBFS.

Hasil analisa dinyatakan dalam bentuk grafik hubungan antara sifat mortar dengan penggunaan variasi GGBFS pada umur yang berbeda, yaitu 7 hari, 14 hari, 21 hari dan 28 hari, sehingga dapat ditentukan optimalisasi penambahan GGBFS.

\section{DATA DAN PEMBAHASAN}

\subsection{Hasil Uji Pendahuluan}

GGBFS yang digunakan untuk pengujian pendahuluan adalah berasal limbah kerak tanur tinggi yang sudah dalam butiran halus (bubuk) yang dan diproduksi PT. Krakatau Semen Indonesia (KSI). Pada uji pendahuluan ini diharapkan dapat diketahui tingkat keaktifan GGBFS. Metode uji yang digunakan adalah NI 20 - 1965, yaitu GGBFS ini dicampur menggunakan kapur padam dengan perbandingan $1 \mathrm{Kp}: 2$ GGBFS. Indikator keaktifan dapat dilakukan dengan menggunakan alat vicat dengan beban 
800 gram, jika dalam 3 hari, jarum vicat dia. $1 \mathrm{~mm}$ setelah dijatuhkan dalam waktu 30 detik dapat masuk ke pasta (campuran bahan GGBFS + kapur padam) di dalam cetakan konik sedalam $\leq 2 \mathrm{~mm}$, maka bubuk GGBFS dinyatakan bersifat aktif.

Hasil uji keaktifan terhadap bubuk GGBFS, dapat dilihat pada Tabel 5 dan Gambar 2.

Tabel 5. Hasil Uji Keaktifan Bubuk GGBFS

\begin{tabular}{|c|c|c|c|c|c|c|c|}
\hline No & Jenis Pengujian & Satuan & Standar Uji & \multirow{2}{*}{ Hasil Uji } & \multicolumn{2}{|c|}{ Spesifikasi NI 20-1965 } & Keterangan \\
\hline 1 & $\begin{array}{l}\text { Keaktifan dengan } \\
\text { Alat Vicat }\end{array}$ & $\mathrm{mm}$ & NI $20-1965$ & 0.0 & - & 2 & Aktif \\
\hline
\end{tabular}

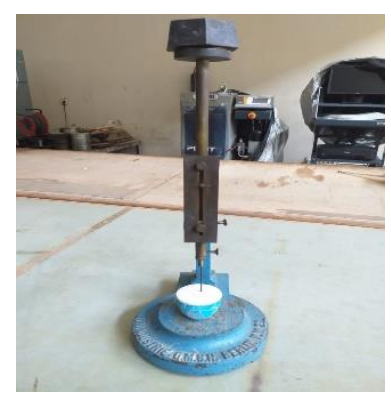

Gambar 2. Uji Keaktifan dengan Alat Vicat

Hasil pengujian menunjukkan bahwa GGBFS bersifat aktif, sehingga dapat digolongkan sebagai bahan pengikat (cementitious material).

\subsection{Hasil Uji Bahan-Bahan Mortar}

Pengujian bahan pembentuk aduk mortar dilakukan hanya pada semen, pasir pasang dan bahan tambah GGBFS saja. Tujuan pengujian ini adalah menentukan kelayakan dari bahan-bahan tersebut, sekaligus digunakan sebagai data untuk perancangan campuran aduk mortar. Adapun terhadap bahan air pencampur tidak dilakukan, karena air yang digunakan adalah air bersih dari sumur dalam di Polban.

\subsubsection{GGBFS}

Dari hasil uji terhadap GGBFS, maka diperoleh hasil pengujian pada tabel 6.

Tabel 6. Uji GGBFS

\begin{tabular}{|c|c|c|c|c|c|c|c|}
\hline \multirow{2}{*}{ No } & \multirow{2}{*}{ Jenis Pengujian } & \multirow{2}{*}{ Satuan } & \multirow{2}{*}{ Standar $\mathrm{Uji}_{\mathrm{ji}}$} & \multirow{2}{*}{ Hasil Uji } & \multicolumn{2}{|c|}{ Spesifikasi } & \multirow{2}{*}{ Keterangan } \\
\hline & & & & & Min & Maks & \\
\hline 1 & Berat Jenis & - & SNI 15-2531-1991 & 2.854 & - & - & \\
\hline \multirow[t]{3}{*}{2} & Bobot Isi & & \multirow{3}{*}{ SNI 03-4804-1998 } & & & & \\
\hline & a. Padat & & & 1.058 & - & - & \\
\hline & b. Gembur & & & 0.993 & - & - & \\
\hline 3 & Kehalusan dengan Blaine & & SNI 15-2049-2004 & 332 & 280 & - & $\begin{array}{c}\text { Memenuhi } \\
\text { Syarat }\end{array}$ \\
\hline
\end{tabular}

\subsubsection{Semen}

Pengujian terhadap semen tipe PCC produksi Semen Tiga Roda, seperti pada tabel 7.

Tabel 7. Uji Semen

\begin{tabular}{|c|c|c|c|c|c|c|c|}
\hline \multirow{2}{*}{ No } & \multirow{2}{*}{ Jenis Pengujian } & \multirow{2}{*}{ Satuan } & \multirow{2}{*}{ Standar $U_{j i}$} & \multirow{2}{*}{ Hasil Uji } & \multicolumn{2}{|c|}{ Spesifikasi } & \multirow{2}{*}{ Keterangan } \\
\hline & & & & & Min & Maks & \\
\hline 1 & Berat Jenis & - & SNI 15-2531-1991 & 2.868 & - & - & \\
\hline 2 & Bobot Isi & & \multirow{3}{*}{ SNI 03-4804-1998 } & & & & \\
\hline & a. Padat & & & 1.223 & - & - & \\
\hline & b. Gembur & & & 1.072 & - & - & \\
\hline
\end{tabular}




\subsubsection{Pasir Pasang}

Pasir yang digunakan adalah pasir pasang dari ex. Garut. Hasil uji terhadap pasir tersebut adalah sebagai berikut :

Tabel 8. Hasil Uji Pasir

\begin{tabular}{|c|c|c|c|c|c|c|c|}
\hline \multirow[t]{2}{*}{ No } & \multirow[t]{2}{*}{ Jenis Pengujian } & \multirow[t]{2}{*}{ Satuan } & \multirow[t]{2}{*}{ Standar $U_{j i}$} & \multirow{2}{*}{$\begin{array}{l}\text { Hasil Uji } \\
\text { Rata-Rata }\end{array}$} & \multicolumn{2}{|c|}{$\begin{array}{c}\text { Spesifikasi } \\
\text { SNI 03-6820-2002 }\end{array}$} & \multirow[t]{2}{*}{ Keterangan } \\
\hline & & & & & Min. & Maks. & \\
\hline \multirow{5}{*}{1} & Berat Jenis & & & & & & \\
\hline & Berat Jenis: SSD & - & \multirow{4}{*}{$\begin{array}{l}\text { ASTM C.128-1997/ } \\
\text { SNI 03-1970-1990 }\end{array}$} & 2.48 & - & - & - \\
\hline & $\begin{array}{l}\text { Berat Jenis: Kering } \\
\text { Oven }\end{array}$ & - & & 2.28 & - & - & - \\
\hline & Berat Jenis: Apparent & - & & 2.85 & - & - & - \\
\hline & Penyerapan Air & $\%$ & & 8.73 & - & - & - \\
\hline 2 & Kada Zat Organik & $\begin{array}{l}\text { Visual } \\
\text { Warna } \\
\end{array}$ & $\begin{array}{c}\text { ASTM C.40-92/ } \\
\text { SNI 03-2816-1992 }\end{array}$ & No. 3 & - & No.3 & \\
\hline 3 & $\begin{array}{l}\text { Kadar butir Lolos } \\
\text { Ayakan } 0,075 \mathrm{~mm}\end{array}$ & $\%$ & $\begin{array}{l}\text { ASTM C.117-1990/ } \\
\text { SNI 03-4142-1996 }\end{array}$ & 12.96 & - & 5 & Harus dicuci \\
\hline \multirow{3}{*}{4} & \multicolumn{7}{|l|}{ Bobot Isi } \\
\hline & Bobot Isi Gembur & $\operatorname{ton} / \mathrm{m}^{3}$ & \multirow{2}{*}{$\begin{array}{l}\text { ASTM C.29-1991/ } \\
\text { SNI 03-4804-1989 }\end{array}$} & 1.40 & - & - & - \\
\hline & Bobot Isi Padat & $\operatorname{ton} / \mathrm{m}^{3}$ & & 1.18 & - & - & - \\
\hline \multirow{11}{*}{5} & Gradasi & & \multirow{11}{*}{$\begin{array}{l}\text { ASTM C.136-1996/ } \\
\text { SNI 03-1968-1990 }\end{array}$} & & & & \\
\hline & Ukuran Ayakan (mm) & & & \multicolumn{3}{|c|}{ Lolos Kumulatif } & \\
\hline & 10.00 & $\%$ & & 100.00 & 100 & 100 & \multirow{8}{*}{$\begin{array}{c}\text { Mendekati } \\
\text { Gradasi } \\
\text { Agregat Aduk } \\
\text { Mortar dengan } \\
\text { Menghilangkan } \\
\text { Butir }>4,75 \mathrm{~mm} \\
\text { dan Mencuci } \\
\text { Agregat }\end{array}$} \\
\hline & 5.00 & $\%$ & & 100.00 & 100 & 100 & \\
\hline & 2.36 & $\%$ & & 84.29 & 90 & 100 & \\
\hline & 1.18 & $\%$ & & 61.58 & 60 & 90 & \\
\hline & 0.60 & $\%$ & & 36.58 & 35 & 70 & \\
\hline & 0.30 & $\%$ & & 21.41 & 10 & 30 & \\
\hline & 0.15 & $\%$ & & 9.53 & 0 & 5 & \\
\hline & $<0.15$ & $\%$ & & 3.26 & 0 & 3 & \\
\hline & Finenes Modulus ( $\mathrm{fm}$ ) & - & & 2.87 & - & - & - \\
\hline 6 & Kadar Air & $\%$ & $\begin{array}{l}\text { ASTM C.566-1989/ } \\
\text { SNI 03-1971-1991 }\end{array}$ & 0.94 & - & - & - \\
\hline
\end{tabular}

Dari hasil pengujian terhadap Pasir pasang ex. Garut dapat disimpulkan bahwa, pasir tersebut mendekati syarat mutu agregat mortar, bila butiran yang tertahan di ayakan 4,75 mm dihilangkan dan agregat dicuci untuk menghilangkan kadar lolos no. 200 yang berlebih.

\subsection{Pengujian Mortar}

\subsubsection{Mortar Segar}

Untuk pengujian mortar segar menggunakan 3 metode pengujian diperoleh hasil pengujiannya sebagai berikut :

\section{a. Konsistensi Mortar}

Pengujian konsistensi mortar ditentukan berdasarkan besarnya kelelehan mortar yang diukur setelah dilakukan pengetukan flow table sebanyak 25 kali dalam waktu 15 detik. Menggunakan alat pengukur kelelehan (Flow Caliper) pada 4 tempat dan besarnya kelelehan mortar adalah penjumlahan keempat pengukuran tersebut.

Hasil pengukuran kelelehan dapat dilihat pada Tabel 9. dan Gambar 3. 
Tabel 9. Nilai Flow Mortar

\begin{tabular}{|c|c|c|}
\hline No & $\begin{array}{c}\text { Penambahan GGBFS } \\
(\%)\end{array}$ & $\begin{array}{c}\text { Nilai Flow Mortar } \\
(\%)\end{array}$ \\
\hline 1 & 0 & 80 \\
\hline 2 & 2 & 80.5 \\
\hline 3 & 4 & 82.5 \\
\hline 4 & 6 & 85 \\
\hline
\end{tabular}

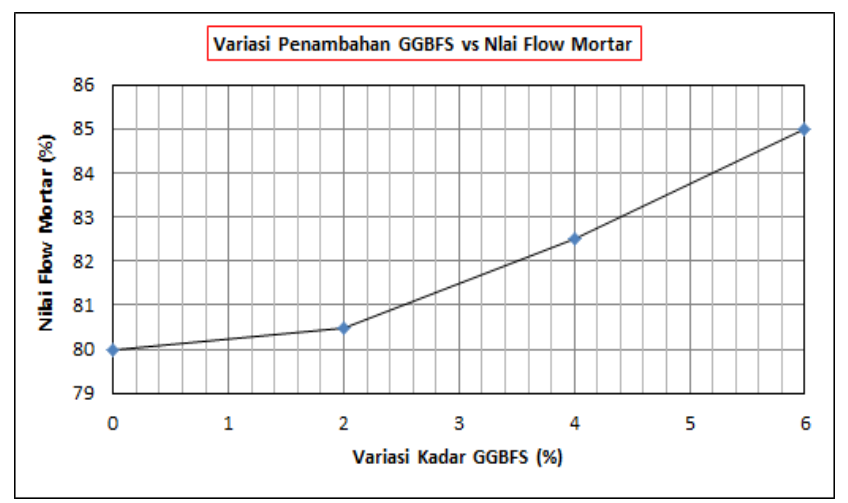

Gambar 3. Grafik Hubungan Variasi Penambahan GGBFS dengan Nilai Flow Mortar

Dari gambar 3., terlihat bahwa dengan penambahan variasi GGBFS ke dalam aduk mortar ternyata meningkatkan nilai flow aduk mortar, yang artinya kekentalan aduk mortar bertambah. Hal ini terlihat untuk penambahan GGBFS dari $2 \%, 4 \%$ dan $6 \%$, menunjukkan aduk mortar semakin plastis, sehingga berdasarkan data di atas ternyata adanya penambahan GGBFS dapat berfungsi sebagai bahan penambah kelecakan (plasticizer material). Besar peningkatan nilai flow aduk mortar dengan penambahan GGBFS $2 \%$ sebesar 0,63\%, penambahan GGBFS $4 \%$ sebesar 3,13\% dan penambahan GGBFS $6 \%$ sebesar $6,25 \%$ terhadap aduk mortar tanpa penambahan GGBFS.

\section{b. Bobot Isi Mortar}

Besarnya berat isi mortar ditentukan berdasarkan perbandingan antara berat mortar terhadap volume mortar. Alat yang digunakan untuk menentukan volume mortar digunakan alat ukur volume yang terbuat dari logam (literan).

Hasil uji berat isi mortar dapat dilihat pada tabel 10. dan gambar 4.

Tabel 10. Nilai Berat Isi mortar Segar

\begin{tabular}{|c|c|c|}
\hline No & $\begin{array}{c}\text { Penambahan GGBFS } \\
(\%)\end{array}$ & $\begin{array}{c}\text { Bobot Isi } \\
\text { Mortar Segar } \\
\left(\mathrm{gr} / \mathrm{cm}^{3}\right)\end{array}$ \\
\hline 1 & 0 & 2.020 \\
\hline 2 & 2 & 2.026 \\
\hline 3 & 4 & 2.029 \\
\hline 4 & 6 & 2.041 \\
\hline
\end{tabular}

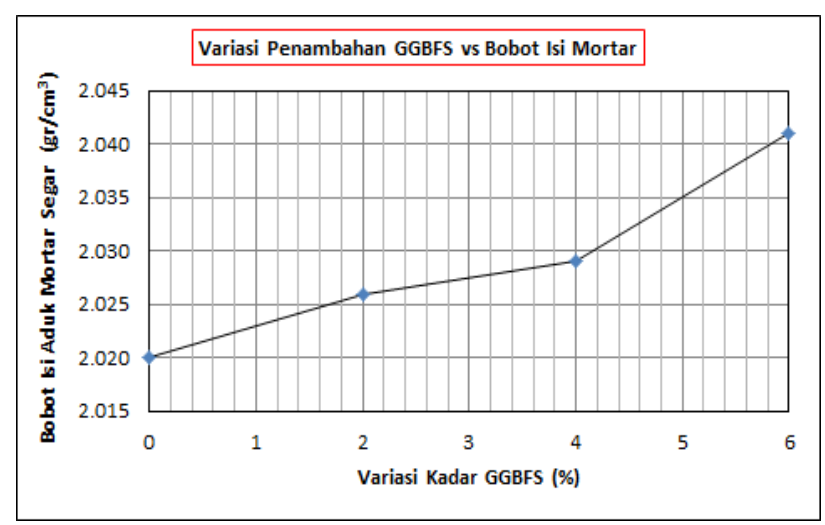

Gambar 4. Grafik Hubungan Variasi Kadar GGBFS dengan Bobot Isi Mortar Segar 
Berdasarkan grafik pada gambar 4, terlihat bahwa semakin besar penambahan GGBFS ditambahkan ke dalam aduk mortar akan meningkatkan bobot isi dari aduk mortar. Besarnya bobot isi aduk mortar dengan penambahan GGBFS 2\% sebesar 0,30\%, penambahan GGBFS $4 \%$ sebesar 0,45\% dan penambahan GGBFS 6\% sebesar 1,04\% terhadap aduk mortar tanpa penambahan GGBFS.

\section{c. Waktu Pengikatan}

Penentuan waktu pengikatan awal mortar didasarkan pada waktu yang diperlukan oleh mortar mulai mengalami perubahan bentuk dari kondisi plastis menjadi mulai kaku. Alat yang digunakan adalah Pocket Penetrometer, yang ditusukkan ke dalam aduk mortar dalam cetakan kubus $10 \times 10 \times 10 \mathrm{~cm}$ sedalam 2,54 cm, jika tekanan telah mencapai $500 \mathrm{lbs}$, maka aduk mortar dinyatakan telah mencapai waktu pengikatan awal. Waktu pengikatan awal mortar dihitung mulai dari tercampurnya air dengan semen, hingga waktu tercapai penusukan dengan tekanan $500 \mathrm{lbs}$.

Tabel 11. Waktu Pengikatan Mortar

\begin{tabular}{|c|c|c|}
\hline No & $\begin{array}{c}\text { Penambahan GGBFS } \\
(\%)\end{array}$ & $\begin{array}{c}\text { Waktu Pengikatan } \\
\text { Awal Mortar } \\
\text { (Menit) }\end{array}$ \\
\hline 1 & 0 & 115 \\
\hline 2 & 2 & 117 \\
\hline 3 & 4 & 120 \\
\hline 4 & 6 & 124 \\
\hline
\end{tabular}

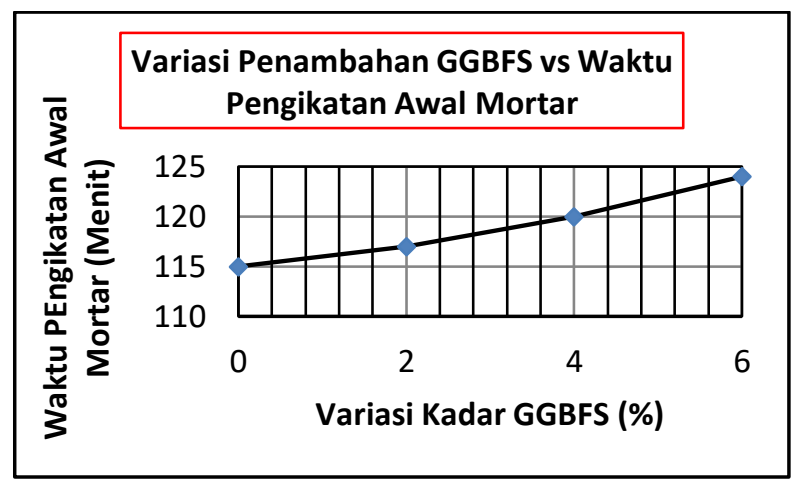

Gambar 5. Grafik Hubungan Variasi Penambahan GGBFS dengan Waktu Pengikatan

Berdasarkan grafik hubungan waktu pengikatan awal mortar dan variasi penambahan GGBFS, terlihat semakin banyak penambahan GGBFS, maka semakin lama waktu pengikatan mortar yang dihasilkan. Besar peningkatan waktu pengikatan awal aduk mortar dengan penambahan GGBFS $2 \%$ sebesar 1,74\%, penambahan GGBFS 4\% sebesar 4,35\% dan penambahan GGBFS $6 \%$ sebesar $7,83 \%$ terhadap aduk mortar tanpa penambahan GGBFS.

\subsubsection{Mortar Keras}

Pengujian mortar keras dilakukan hanya berdasarkan 2 jenis pengujian, yaitu uji bobot isi dan kekuatan tekan menggunakan benda uji kubus mortar berukuran 5 x 5 x $5 \mathrm{~cm}$. Hasil pengujiannya sebagai berikut :

\section{a. Uji Bobot Isi}

Bobot isi keras adalah perbandingan antara berat dan volume benda uji kubus mortar 5 x 5 x $5 \mathrm{~cm}$ setelah benda uji tersebut mengeras

Hasil uji berat isi mortar dapat dilihat pada tabel 12 dan gambar grafik 6 .

Tabel 12. Berat Isi Mortar Keras

\begin{tabular}{|c|c|c|c|c|}
\hline \multirow{2}{*}{$\begin{array}{c}\text { Umur } \\
\text { (hari) }\end{array}$} & \multicolumn{4}{|c|}{ Bobot Isi Mortar $\left(\mathrm{gr} / \mathrm{cm}^{3}\right)$} \\
\cline { 2 - 5 } & 0 & 2 & 4 & 6 \\
\cline { 2 - 5 } & 0 & 1.780 & 1.773 & 1.786 \\
\hline 7 & 1.775 & 1.779 & 1.777 & 1.784 \\
\hline 14 & 1.783 & 1.787 & 1.787 & 1.798 \\
\hline 21 & 1.805 & 1.79 Penambahan GGBFS \\
\hline 28 & 1.807 & 1.799 & 1.806 & 1.808 \\
\hline
\end{tabular}




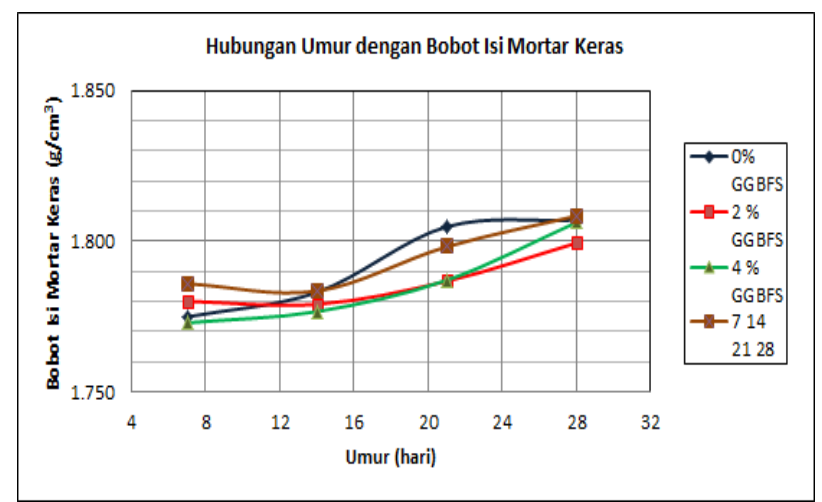

Gambar 6. Hubungan Variasi penambahan GGBFS dengan Bobot Isi Mortar Keras

Dengan menambahkan GGBFS sebesar 4 dan $6 \%$ ke dalam aduk mortar, dapat meningkatkan bobot isi mortar keras walaupun relatif kecil, yaitu sebesar $0,11 \%$ dan $0,88 \%$, kecuali pada penambahan GGBFS $2 \%$ terjadi penurunan bobot isi mortar sebesar $0,42 \%$. Dari hasil pengujian terhadap bobot isi mortar keras relatif perubahannya kecil.

\section{b. Kuat tekan}

Salah satu sifat mekanis dari mortar adalah kuat tekan yang dihitung berdasarkan perbandingan beban maksimum dibagi luas bidang tekan atau kemampuan mortar untuk dapat memikul beban tekan persatuan luas. Jadi semakin tinggi nilai kuat tekan mortar, maka semakin besar beban yang dapat dipikul mortar atau kualitas semakin baik.

Benda uji yang digunakan untuk menentukan kuat tekan adalah kubus $5 \mathrm{~cm}$ x $5 \mathrm{~cm}$ x $5 \mathrm{~cm}$. Hasil uji kuat tekan dapat dilihat pada tabel 13 dan gambar 7.

Tabel 13. Kuat Tekan Mortar

\begin{tabular}{|c|c|c|c|c|}
\hline \multirow{2}{*}{$\begin{array}{c}\text { Umur } \\
\text { (hari) }\end{array}$} & \multicolumn{4}{|c|}{ Kuat Tekan Mortar (Mpa) } \\
\cline { 2 - 5 } & 0 & 2 & 4 & 6 \\
\hline & 0.43 & 3.58 & 7.67 & 7.30 \\
\hline 7 & 5.43 Penambahan GGBFS \\
\hline 14 & 6.63 & 7.39 & 8.82 & 7.69 \\
\hline 21 & 7.62 & 7.61 & 9.27 & 10.58 \\
\hline 28 & 7.97 & 8.35 & 10.36 & 10.66 \\
\hline
\end{tabular}

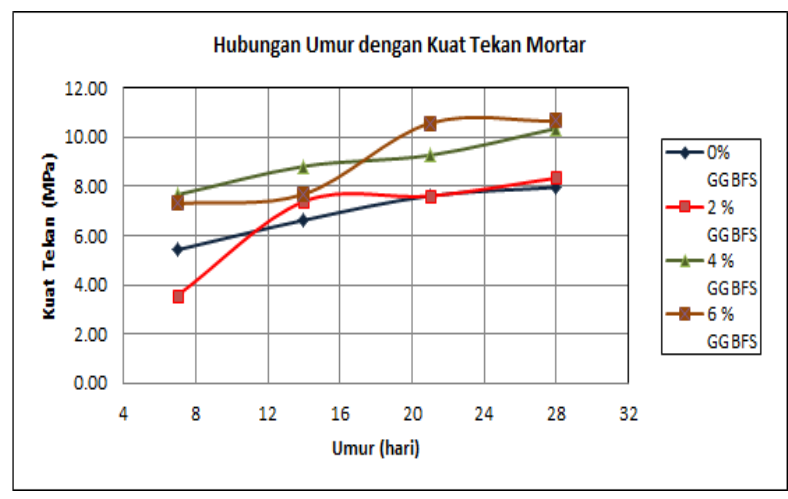

Gambar 7. Hubungan Variasi Penambahan GGBFS dengan kuat tekan

Adanya penambahan variasi bubuk GGBFS ke dalam mortar ternyata meningkatkan kekuatan mortar pada 7 hari pertama. Hal ini terlihat dari gambar 7. ternyata seluruh mortar yang diberi tambahan GGBFS lebih besar dibanding mortar tanpa penambahan GGBFS. Dari grafik di atas menunjukkan bahwa semakin besar penambahan GGBFS pada aduk mortar, maka semakin tinggi kekuatan tekan mortar yang dihasilkan terutama pada aduk mortar dengan umur antara 21 dan 28 hari. Penambahan variasi GGBFS pada aduk mortar, kemungkinan disebabkan butiran GGBFS yang halus sehingga dapat mengisi rongga di antara butiran agregat halus dan semen, serta sifat aktifnya GGBFS dapat membentuk ikatan tambahan bahan perekat akibat reaksi antara bahan posolan dengan kapur bebas yang dihasilkan dari reaksi semen dan air. 


\section{KESIMPULAN}

\subsection{Kesimpulan}

Setelah penulis melakukan penelitian terhadap penambahan GGBFS sebagai bahan tambah aduk mortar, maka penulis berkesimpulan sebagai berikut :

a. GGBFS adalah bahan pozolanik yang bersifat aktif, sehingga dapat digunakan sebagai bahan pengganti menggantikan semen $P P C$ dalam batasan tertentu, karena memiliki kehalusan $\leq$ dengan ukuran butir semen.

b. Penambahan GGBFS sebesar $2 \%$ - $6 \%$ ke dalam aduk mortar akan dapat meningkatkan workability aduk mortar sebesar 0,3\% s/d 1,04\% terhadap aduk mortar tanpa penambahan GGBFS, karena bahan ini bersifat meningkatkan plastisitas.

c. Sebaliknya penambahan GGFS antara $2 \% \mathrm{~s} / \mathrm{d} 6 \%$ ke dalam aduk mortar akan meningkatkan waktu pengikatan awal sebesar $1,74 \%$ s/d 7,83\%. Jadi semakin besar penambahan GGBFS akan memperlama waktu pengikatan awal aduk mortar.

d. Adanya penambahan $G G B F S$ dalam aduk mortar meningkatkan kekuatan mortar pada umur 28 hari yang relatif besar, yaitu pada penambahan GGBFS 4\% diperoleh penambahan kekuatan sebesar 30,07\% dan untuk penambahan GGBFS 6\% diperoleh penambahan kekuatan sebesar 33,77\%.

\subsection{Saran}

Beberapa saran yang penulis rasakan perlu dikemukakan selama melakukan penelitian ini adalah sebagai berikut :

a. Penelitian penambahan GGBFS ke dalam aduk mortar perlu ditindak lanjuti dengan penelitian dengan jumlah penambahan GGBFS yang lebih dari $6 \%$, sehingga akan dapat diketahui optimasi kadar GGBFS yang dapat ditambahkan ke dalam aduk mortar.

b. Perlu dilakukan kajian pemanfaatan GGBFS dengan beberapa jenis mortar dengan yang berbeda, sehingga dapat diperoleh efektivitas pemanfaatan GGBFS.

\section{DAFTAR PUSTAKA}

[1]. Abdul Karim G, Susilowati E dan Pratiwi W., 2018. Pengaruh Ground Granulated Blast Furnace Slag Terhadap Sifat Fisika Semen Portland Jenis-I . Jurnal Teknologi Bahan dan Barang Teknik Vol.8, No.2, Desember 2018: 47-52

[2]. ACI Committee 116, Cement and Concrete Terminology (ACI 116R-90), American Concrete Institute, Farmington Hills, MI, 1990

[3]. ASTM C 1077-92, Standard Practice for Laboratories Testing Concrete and Concrete Aggregates for Use in Construction and Criteria for Laboratory Evaluation, ASTM, West Conshohocken, PA

[4]. Barnett S. J., Soutsos M. N., Millard S. G. dan Bungey J. H. 2006, Strength development of mortars containing ground granulated blast-furnace slag: Effect of curing temperature and determination of apparent activation energies, Cement and Concrete Research, 36, p. 434-440.

[5]. Hirde, S., dan Pavin, G.,2015 .Effect of Addition of Ground Granulated Blast Furnace Slag (GGBS) on Mechanical Properties of Fibre Reinforced Concrete. International Journal of Current Engineering and Technology, 5(3), 1678-1682.

[6]. Nursyafril . 2010, Pengaruh Penggunaan Abu Batubata Terhadap Sifat Aduk Mortar. Jurnal Potensi.

[7]. Sulastari, 1996, Kuat Tekan dan Kuat Tarik Mortar Semen Dengan Semen Portland Biasa dan Semen Portland Pozzolan, Tugas Akhir, Jurusan Teknik Sipil Fakultas Teknik Universitas Gadjah Mada (UGM), Yogyakarta.

[8]. Putri, L.K. 2017. Pengaruh Material Aktif Pozzolan terhadap Pembentukan Kekuatan Mortar. Gresik: Laporan Penelitian Praktek Kerja Lapangan PT. Semen Indonesia (Persero)

[9]. Saripoelman. 2009.’Mengenal Lebih Jauh Mengenai Mortar, Bagian 1".

[10]. Badan Standardisasi Nasional, 2015. SNI 15-2049-2015, Semen Portland - Bahan Bangunan, Jakarta, BSN.

[11]. SNI 6385:2016, Spesifikasi Semen Slag untuk Digunakan dalam Beton dan Mortar. Jakarta, BSN

[12]. Siddique R., dan Bennacer R. 2012, Use of iron and steel industry by-product (GGBS) in cement paste and mortar, Resources Conservation and Recycling, 69, p. 29-34.

[13]. SNI 6882:2014. Spesifikasi mortar untuk pekerjaan unit pasangan. Badan Standardisasi Nasional

[14]. Tjokrodimulyo. 1996. Teknologi Beton, Yogjakarta.

[15]. Takehisa, D., N. Nakajima, Y. Uno, dan S. Date. 2017. Effect of Setting Accelerator to the Initial Strength of Mortar with Blast Furnace Slag Cement. In IOP Conference Series: Materials Science and Engineering, 264:12003. 